\title{
PRAKTYKA WYKORZYSTYWANIA INTERNETU W ZWALCZANIU PRZESTĘPCZOŚCI PRZECIWKO ZABYTKOM
}

\begin{abstract}
Streszczenie. Obserwujemy zmiany w toku rozwoju nauk, z których kryminalistyka czerpie wiedzę i z których osiągnięć korzysta, przystosowując je do walki z przestępczością. Współczesna kryminalistyka nie poprzestaje na samej adaptacji zdobyczy innych nauk, ale również samodzielnie opracowuje własne metody i środki do walki z przestępczością, co wiąże się z ciągłym postępem technicznym i rosnącymi potrzebami organów ścigania i kryminalistyki. Zgromadzone w trakcie czynności ślady kryminalistyczne możemy dziś zidentyfikować, stosując nowoczesne technologie. Jest to obecnie możliwe, również dzięki uzyskanym nowym źródłom osobowym oraz ciężkiej pracy analitycznej, dochodzeniowej i operacyjnej. Jak pokazuje praktyka, podstawą wszczynania postępowania mogą być również dowody elektroniczne, które można znaleźć, analizując zawartość Internetu.
\end{abstract}

Słowa kluczowe: broń, prawo, archeologia, zabytek, kryminalistyka, informatyka śledcza.

Procesowo kryminalistyczne czynności dowodowe mają istotne znaczenie w walce z przestępczością, co do tego nikt nie ma wątpliwości. Wprowadzanie nowych instytucji, a także zmiany w już istniejących przepisach, nakładają obowiązek ciągłego kształcenia się w celu umiejętnego oraz skutecznego stosowania prawa. Obserwujemy zmiany w toku rozwoju nauk, z których kryminalistyka czerpie wiedzę i z których osiągnięć korzysta, przystosowując je do walki z przestępczością. Współczesna kryminalistyka nie poprzestaje na samej adaptacji zdobyczy innych nauk, ale również samodzielnie opracowuje własne metody i środki do walki z przestępczością, co wiąże się z ciągłym postępem technicznym i rosnącymi potrzebami organów ścigania i kryminalistyki.

Wielokrotnie podczas dyskusji dotyczących prowadzonych postępowań poruszana jest tematyka związana z uzyskanym materiałem dowodowym oraz skutecznym podejmowaniem, nawet po latach od umorzenia, postępowań przygotowawczych. Odnosi się to do spraw umorzonych z powodu niewykrycia sprawców, które pomimo ustaleń i śladów kryminalistycznych zabezpieczonych przed laty nie doprowadziły do rozwiązania zagadki kryminalnej. Zgromadzone w trakcie czynności ślady kryminalistyczne możemy dziś zidentyfikować, stosując nowoczesne technologie. Jest to obecnie możliwe również dzięki uzyskanym nowym źródłom osobowym oraz ciężkiej pracy analitycznej, dochodzeniowej i operacyjnej. Jak

\footnotetext{
*Komenda Główna Policji, adam.ggg1@wp.pl.
} 
pokazuje praktyka, podstawą wszczynania postępowania mogą być też dowody elektroniczne, znalezione podczas analizowania zawartości Internetu.

Każda informacja $\mathrm{w}$ formie elektronicznej, która może mieć znaczenie dowodowe, może być dowodem w sprawie. Jak powszechnie wiadomo, dowodem w postępowaniu karnym jest każdy dopuszczalny przez prawo karne procesowe środek służący do dokonania ustaleń, które służą ustaleniu okoliczności mających znaczenie dla rozstrzygnięcia. Jednocześnie, zgodnie z zasadą prawdy materialnej (art. $2 \S 2$ k.p.k.), podstawę do wszelkich rozstrzygnięć powinny stanowić prawdziwe ustalenia faktyczne (Grzegorczyk, Tylman 2005, 417-419). Podstawowymi źródłami dowodowymi mogą być: komputery, telefony komórkowe i inne urządzenia mobilne, nośniki zewnętrzne, systemy księgowe, bazy danych, serwery i szeroko pojęte dane internetowe. Dowodami elektronicznymi mogą być na przykład dane w postaci tekstów lub informacji z forów internetowych, a także informacje ze skrzynek e-mailowych i oferty sprzedaży z portali internetowych (Saramak 2015, 108-110; Mądrzejowski 2012, 117-128). Dowodem mogą być dane graficzne lub numeryczne zapisane w postaci zdjęć lub filmu, rysunku, mapy albo nagranej rozmowy lub zapisu kamery internetowej. Mogą to być również pliki dźwiękowe lub wizualno-dźwiękowe w postaci amatorskiego filmu z telefonu komórkowego. Zgromadzenie dowodów polega m.in. na zabezpieczeniu danych i stworzeniu ich kopii. Rola informatyki śledczej to dostarczanie elektronicznych dowodów pozwalających na wykrywanie przestępstw dokonanych z użyciem komputera lub innych urządzeń elektronicznych. Jest to dziedzina, której celem jest zabezpieczenie i analiza środków dowodowych zawartych na nośnikach cyfrowych. Informatyka śledcza nie zajmuje się samym odzyskiwaniem danych. Jest to jedynie jeden ze wczesnych etapów całego procesu stanowiącego często podstawę do wszczynania postępowania przygotowawczego. Jest to wzbogacanie często niepełnej wiedzy dotyczącej czynu przestępczego.

Informatyka śledcza jest blisko spokrewniona z kryminalistyką, ponieważ wiąże się z poszukaniem elektronicznych śladów mogących mieć istotne znaczenie w postępowaniu karnym. Znajduje ona zastosowanie niemal we wszystkich rodzajach przestępczości, głównie w wykrywaniu przestępstw gospodarczych, seksualnych, samochodowych, oszustw internetowych, a także przestępczości przeciwko zabytkom (Trzciński 2010, 187-200). Informatyk śledczy zajmuje się poszukiwaniem i wykrywaniem dowodów nadużyć i przestępstw, które zostały dokonane przy użyciu komputera, są na nim przechowywane lub za jego pośrednictwem udostępnione innym osobom. Skupia się on również na śladach przestępczości lub informacjach o nich udostępnionych innym osobom drogą internetową (Stromczyński, Waszkiewicz 2014, 158-163). Odnalezione w ten sposób elektroniczne informacje mogą być wykorzystane jako materiały dowodowe w sądzie. W celu wykrywania i zapobiegania przestępczości komputerowej coraz częściej prowadzony jest monitoring ruchu internetowego. W Polsce zajmują się tym przede wszystkim policjanci z Wydziałów do Walki z Cyberprzestępczością 
lub wąskie grono funkcjonariuszy z innych wydziałów policji, którzy specjalizują się w różnych rodzajach przestępczości (Gruza, Moszczyński 2011, 571-572).

W celu skutecznego monitorowania tego zagadnienia, oprócz jego znajomości, niezbędna jest wiedza na temat funkcjonowania mechanizmów nielegalnego obrotu zabytkami, a także szeroko pojęta znajomość prawa ochrony zabytków. Przepisami, od których należałoby rozpocząć dyskusję na temat problematyki przestępczości przeciwko zabytkom, jest ustawa o ochronie zabytków i opiece nad zabytkami. Najczęstszym zjawiskiem, na temat którego znajdujemy liczne dowody w Internecie, jest przestępczość związana $\mathrm{z}$ nielegalnie prowadzonymi poszukiwaniami zabytków i nielegalnym obrotem zabytkami archeologicznymi. Dokonywane jest to za pośrednictwem internetowych portali aukcyjnych, forów internetowych wymieniających informacje pomiędzy poszukiwaczami zabytków lub innych portali społecznościowych, za pomocą których użytkownicy prezentują przedmioty uzyskane w trakcie działalności przestępczej (Ziółkowski 2006, 13-15). Zgodnie z art. 36 ustawy z dnia 23 lipca 2003 r. o ochronie zabytków i opiece nad zabytkami (Dz. U. 2003, Nr 162, poz. 1568, dalej: u.o.o.z.) zarówno prowadzenie badań archeologicznych, jak i poszukiwanie zabytków, w tym też archeologicznych, wymaga pozwolenia wojewódzkiego konserwatora zabytków (zob. rozporządzenie Ministra Kultury i Dziedzictwa Narodowego z dnia 27 lipca 2011 r. w sprawie prowadzenia prac konserwatorskich, prac restauratorskich, robót budowlanych, badań konserwatorskich, badań architektonicznych i innych działań przy zabytku wpisanym do rejestru zabytków oraz badań archeologicznych, Dz. U. 2011, Nr 165, poz. 987). Brak wymaganego ustawowo pozwolenia albo prowadzenie poszukiwań wbrew jego warunkom jest naruszeniem z art. 111 u.o.o.z. i stanowi wykroczenie. Nieco inna sytuacja ma miejsce w przypadku, gdy poszukiwania obejmują tereny, na których znajdują się stanowiska archeologiczne, miejsca martyrologii czy mogily. Możemy wówczas mieć do czynienia z przestępstwami niszczenia i przywłaszczenia zabytków. Mechanizm niszczenia zabytków obejmuje zabytki ruchome i nieruchome. Osoby, które dokonują wszelkiej ingerencji w warstwy gleby na stanowisku archeologicznym, nawet w celu poszukiwaniu zabytków, doprowadzają do uszkodzenia zabytków. Mowa oczywiście o działaniu niezwiązanym z uzasadnionymi badaniami naukowymi. Takie przestępcze działanie prowadzi do bezpowrotnego niszczenia nawarstwień kulturowych i znajdujących się w nich wytworów rąk ludzkich oraz nie ma nic wspólnego $\mathrm{z}$ ustawowymi badaniami, którymi według definicji art. 3 u.o.o.z. są działania mające na celu odkrycie, rozpoznanie, udokumentowanie i zabezpieczenie zabytku archeologicznego. Bezpodstawne wykopywanie zabytków archeologicznych z ziemi, pozbawiające ich kontekstu historycznego, brak ich odpowiedniego opracowania naukowego i konserwacji również można zakwalifikować jako niszczenie zabytku. Taki sposób działania doprowadza do niszczenia zabytków nieruchomych w postaci stanowisk archeologicznych i znajdujących się w jego nawarstwieniach ruchomych zabytków archeologicznych. Rozkopywanie i naruszanie warstw stratygraficznych na stanowiskach archeologicznych w celu 
pozyskiwania zabytków jest naruszeniem art. 108 u.o.o.z., z czym mamy do czynienia w tym przypadku (Gadecki 2014, 16; Trzciński 2010, 49-60; Gadecki 2015, 56-57). Opisane powyżej zachowanie wypełnia znamiona przestępstwa $\mathrm{z}$ art. 108 u.o.o.z. zagrożonego karą od 3 miesięcy do 5 lat pozbawienia wolności. W sytuacji, gdy przez nielegalne wykopaliska zostanie zniszczone miejsce bądź przedmiot stanowiący dobro o szczególnym znaczeniu dla kultury, mamy do czynienia z art. 294 $\S 2$ ustawy z dnia 6 czerwca 1997 r. Kodeks karny (Dz. U. 1997, Nr 88, poz. 553; dalej: k.k.), stanowiącym typ kwalifikowany określony przez katalog przestępstw w § 1 art. 294 k.k., w skład którego wchodzi również przestępstwo kradzieży (art. 278 k.k.). Przepis ten zastosowany w przypadku dobra o szczególnym znaczeniu dla kultury wyraźnie zaostrza sankcję karną od roku do 10 lat pozbawienia wolności (Bernatek-Zaguła 2012, 135-149; zob. też k.k.). Osoby pozyskujące zabytkowe przedmioty podczas poszukiwań bez wymaganego przez ustawę pozwolenia dopuszczają się przestępstwa przywłaszczenia lub kradzieży tych przedmiotów na szkodę Skarbu Państwa. Takie działanie jest niezgodne z normą prawną zawartą w art. 278 i 284 k.k. (Grześkowiak, Wiak 2014, 974-975). Wynika to wprost z art. 35 ust. 1 i 2 ustawy o ochronie zabytków i opiece nad zabytkami, według którego znalezione przedmioty, co do których można przypuszczać, że stanowią zabytek archeologiczny, należą do Skarbu Państwa (np. art. 284 k.k. w zW. z art. 35 u.o.o.z.). Przedmioty będące zabytkami archeologicznymi wyłączone są również z obrotu handlowego, natomiast ich nielegalne nabycie i posiadanie jest przestępstwem. Zgodnie z zapisem art. 189 kodeksu cywilnego i ze zmianami, jakie wprowadzone zostały w 2015 r. przez ustawę o rzeczach znalezionych, w przypadku gdy rzecz niebędąca zabytkiem, materiałem archiwalnym znaleziona została $\mathrm{w}$ takich okolicznościach, że poszukiwanie właściciela byłoby oczywiście bezcelowe, staje się przedmiotem współwłasności w częściach ułamkowych znalazcy i właściciela nieruchomości, na której rzecz została znaleziona (zob. ustawa z dnia 20 lutego 2015 r. o rzeczach znalezionych, Dz. U. 2015, poz. 397, dalej: u.o.rz.z.; ustawa z dnia 23 kwietnia 1964 r. Kodeks cywilny, Dz. U. 1964, Nr 16, poz. 93, dalej: k.c.). W takim wypadku znaleziony przedmiot, który nie jest zabytkiem, obciążony jest prawami własności innych osób. W tym samym artykule ustawodawca dodaje, iż w przypadku gdy rzecz ta jest zabytkiem lub materiałem archiwalnym, staje się ona własnością Skarbu Państwa, a znalazca jest obowiązany wydać ją niezwłocznie właściwemu staroście. Nowa ustawa doprecyzowała sporną kwestię dotyczącą roszczeń zarówno w przypadku przedmiotów znalezionych, jak i znalezionych przedmiotów, które posiadają cechy zabytku. Jak wynika z analizy aktów prawnych, rzeczy niebędące zabytkami to takie, które nie spełniają definicji stypizowanej w ustawie o zabytkach i opiece nad zabytkami, jednak największe kompetencje do rozstrzygnięcia tego problemu posiada przede wszystkim konserwator zabytków, a nie znalazca. Często przedmiotem kolekcjonerów oraz poszukiwaczy zabytków jest broń i inne pamiątki stanowiące wyposażenie żołnierskie. Przedmioty takie są najczęściej oferowane na internetowych portalach aukcyjnych, a także 
prezentowane $\mathrm{i}$ omawiane na specjalistycznych dyskusyjnych forach internetowych. Często wejście w posiadanie takich przedmiotów, co wynika z dotychczasowej praktyki, jest ściśle powiązane z prowadzeniem poszukiwań z wykrywaczem metalu. Zwrócić należy również uwagę, że nielegalne posiadanie broni i amunicji znalezionej lub wykopanej, pomimo iż broń może spełnić definicje zabytku, zgodnie z art. $263 \S 2$ k.k., jest przestępstwem. Na posiadanie broni, również w celach kolekcjonerskich, wymagane jest pozwolenie (art. 10 ustawy z dnia 21 maja 1999 r. o broni i amunicji, Dz. U. 1999, Nr 53, poz. 549; zob. też k.k.). Posiadanie bez pozwolenia elementów broni palnej i amunicji nie jest jedynym problemem, ponieważ na terenach niegdyś objętych działaniami wojennymi do tej pory znajdowane są materiały niebezpieczne, takie jak miny, granaty czy pociski artyleryjskie. Pomijając to, że znaleziska te mogą stanowić realne zagrożenie dla życia i zdrowia, ich posiadanie i przechowywanie stanowi przestępstwo z art. 171 k.k. Pomijając, iż posiadanie ich jest zabronione, niektóre $\mathrm{z}$ tych przedmiotów z uwagi na posiadane cechy i miejsce odkrycia mogą spełniać definicję zabytku, a tym bardziej zabytku archeologicznego, opisaną w art. 3 ustawy o ochronie zabytków i opiece nad zabytkami. Zupełnie innym zagadnieniem, chociaż mającym wielokrotnie związek z nielegalnym poszukiwaniem zabytków, jest okradanie mogił lub grobów wojennych. Przestępstwo to jest bardzo trudne do ujawnienia. Przyczyną tego jest przede wszystkim sposób działania sprawców i miejsce dokonywania przestępstwa, które wielokrotnie pozwala zachować anonimowość osobom trudniącym się tym procederem. Głównie przyczynia się do tego umiejscowienie oddalonych od skupisk ludzkich mogił i cmentarzy wojennych. Sprawę komplikuje również fakt, iż niektóre miejsca pochówku do tej pory są nierozpoznane lub zupełnie powierzchniowo nieczytelne. Zgodnie z obowiązującymi aktami prawnymi, każde bezpodstawne wyjmowanie zwłok lub szczątków ludzkich z grobu lub innego miejsca spoczynku zmarłego jest czynem zabronionym, którego sprawca wypełnia znamiona przestępstwa z art. $262 \S 1$ k.k. O bezpodstawnym wyjęciu z grobu mówimy w sytuacji, gdy jest to wykonywane bez stosownych pozwoleń i postanowień określonych przez obowiązujące przepisy, do których wydawania uprawnieni są prokurator, sędzia, Prezes Instytutu Pamięci Narodowej lub konserwator zabytków. Zaznaczyć należy, że takie przestępcze działania w stosunku do grobów i cmentarzy wojennych doprowadzają do naruszenia postanowień obowiązujących umów międzynarodowych (zob. umowa między Rządem Rzeczypospolitej Polskiej a Rządem Republiki Federalnej Niemiec o grobach ofiar wojen i przemocy totalitarnej, podpisana w Warszawie dnia 8 grudnia 2003 r., M.P. z dnia 23 września 2005 r.; umowa między Rządem Rzeczypospolitej Polskiej a Rządem Federacji Rosyjskiej o grobach i miejscach pamięci ofiar wojen i represji, sporządzona w Krakowie dnia 22 lutego 1994 r., Dz. U. z dnia 21 października 1994 r.) $)^{1}$. Znieważenie realizują również takie zachowania, jak zmiana ustalonego położenia zwłok i przeznaczenia grobu oraz

\footnotetext{
${ }^{1}$ Sprawa Ds. 405/12 prowadzona przez Prokuraturę Rejonową w Pabianicach.
} 
rozkopanie grobu. Zgodnie z obowiązującymi przepisami kodeksu karnego ograbianie zwłok, grobu lub innego miejsca spoczynku zmarłego jest przestępstwem, o czym stanowi art. 262 § 2 k.k. (Grześkowiak, Wiak 2014, 974-975; Stefański 2004, 19-28). Bezwzględnie nie można takiego procederu nazywać ekshumacją. Zauważyć należy, że miejsca pochówku poległych żołnierzy, takie jak cmentarzyska z minionych epok, również posiadają cechy zgodne z definicją zabytku (Gadecki 2014, 41; Grajewski 2016a, 87-102). Nieco odmienna sytuacja kształtuje się w przypadku utraty zabytku bądź dzieła sztuki w wyniku kradzieży lub kradzieży z włamaniem do obiektu muzeum lub prywatnej nieruchomości. W tym przypadku niemalże od razu wiadomo, co zostało utracone w wyniku przestępstwa. Zgodnie z zapisem art. 23 ust. 1 u.o.o.z., krajowy wykaz zabytków skradzionych lub wywiezionych za granicę niezgodnie z prawem jest narzędziem służącym do identyfikacji i poszukiwań utraconych dóbr kultury (zob. u.o.rz.z.) $)^{2}$. Jest on prowadzony przez Narodowy Instytut Muzealnictwa i Ochrony Zbiorów, który w tym celu gromadzi materiały niezbędne do identyfikacji zabytku. Wykaz jest również dostępny w wersji internetowej, co powoduje, iż jest powszechnym i skutecznym narzędziem pracy dla zainteresowanych podmiotów. Wszystkie utracone w wyniku przestępstwa zabytki powinny zostać zarejestrowane w katalogu utraconych zabytków, co rozszerza możliwość dostępu do informacji o poszukiwanych dobrach kultury. Art. 26 ustawy o rzeczach znalezionych wprowadził zmiany w art. 223 kodeksu cywilnego, dodając $\S 4$. Przytaczany art. $223 \S 4$ k.c. stanowi, iż roszczenie właściciela rzeczy wpisanej do krajowego rejestru utraconych dóbr kultury nie ulega przedawnieniu (zob. u.o.rz.z.; k.c.). Nowa ustawa doprecyzowała sporną kwestię dotyczącą przedawnienia roszczeń w przypadku zabytków i dzieł sztuki (Rudnicki, Rudnicka, Rudnicki 2016, 508-536). Zgodnie z nowelizacją ustawy o ochronie zabytków i opiece nad zabytkami, jakie po zmianach w 2015 r. wprowadziła ustawa o rzeczach znalezionych, taka sytuacja może mieć miejsce, gdy rzecz stanowiąca dobro narodowe zostanie utracona. Ustawodawca wprost wskazuje, iż roszczenie takie nie ulega przedawnieniu, gdy wskutek przestępstwa kradzieży (art. 278 k.k.), kradzieży z włamaniem (art. 279 k.k.), rozboju (art. 280 k.k.), kradzieży rozbójniczej (art. 281 k.k.), wymuszenia rozbójniczego (art. 282 k.k.), przywłaszczenia (art. 284 k.k.) kolekcja bądź pojedynczy element zbiorów, stanowiące według definicji prawnej muzealia, o których mowa w art. 21 ustawy o muzeach, zostaną utracone przez właściciela (ustawa z dnia 21 listopada 1996 r. o muzeach, Dz. U. 2012, poz. 987; por. k.k.; zob. u.o.o.z.). Warunkiem jest, zgodnie z art. 24a u.o.o.z., aby wraz z dokumentacją fotograficzną i opisem określającym indywidualne, pozwalające na identyfikację cechy zostały wpisane do krajowego rejestru dóbr kultury na wniosek policji, prokuratora, wojewódzkiego konserwatora zabytków, Naczelnego Dyrektora Archiwów Państwowych, właściciela rzeczy, o której mowa w ust. 2, lub osoby kierującej jednostką organizacyjną, w zbiorach albo zasobach której rzecz się

\footnotetext{
${ }^{2}$ http://www.nimoz.pl [dostęp 15.02.2017].
} 
znajdowała (zob. u.o.rz.z.). Zgodnie z art. 24d u.o.o.z. nikt od dnia dokonania wpisu w krajowym rejestrze utraconych dóbr kultury nie może zasłaniać się nieznajomością danych ujawnionych w tym rejestrze (Michalak, Ginter 2016, 144-156). Rejestracja utraconych zabytków jest bardzo istotna, ponieważ ułatwia ich odzyskanie nawet po wielu latach od ich kradzieży, również w przypadku ich nielegalnego wywozu poza granicę naszego kraju (art. 109 u.o.o.z.).

Jako jedną z wielu przykładów roli informatyki śledczej w zwalczaniu przestępczości przeciwko zabytkom można przytoczyć sprawę odzyskania zabytku malarstwa. Pod koniec 2011 r. funkcjonariusze Zespołu do Walki z Przestępczością Przeciwko Dziedzictwu Narodowemu Wydziału Kryminalnego KWP w Łodzi otrzymali informację wskazującą, iż w Internecie oferowany jest do sprzedaży obraz podobny do widniejącego w wykazie strat wojennych Ministerstwa Kultury. Na kanwie tej informacji przeprowadzono wnikliwą analizę internetowych aukcji dzieł sztuki oferowanych przez domy aukcyjne. Zaczęto gromadzić informacje dostępne w Internecie ${ }^{3}$. Dodatkowym narzędziem pomocnym przy pracy śledczych były internetowe katalogi utraconych zabytków. Ustalono, że podobny obraz jest poszukiwany jako strata wojenna. Po przeanalizowaniu internetowych aukcji okazało się, że był on wystawiany na aukcjach internetowych przez kilka domów aukcyjnych. Jednocześnie ustalono, że aktualnie jest on wystawiony przez jeden z domów aukcyjnych znajdujących się na terenie Łodzi. Dzięki analizie zebranych za pośrednictwem Internetu informacji, funkcjonariusze podjęli decyzję o podjęciu działań zmierzających do zabezpieczenia obrazu. W trakcie czynności ujawnili i zabezpieczyli poszukiwany obraz autorstwa Teodora Axentowicza, zatytułowany Kobieta w pawich piórach. Obraz znajdował się w wykazie strat wojennych prowadzonym przez Ministerstwo Kultury oraz był zarejestrowany w wykazie skradzionych zabytków, prowadzonym przez NIMOZ ${ }^{4}$. Zaginął w 1939 r. w niewyjaśnionych okolicznościach w czasie działań wojennych. Był on wtedy własnością Towarzystwa Zachęty Sztuk Pięknych w Warszawie. Zabezpieczony w trakcie czynności obraz poddano ekspertyzom kryminalistycznym, do których powołano biegłych z zakresu historii sztuki i malarstwa okresu twórczości Teodora Axentowicza, którzy stwierdzili jego autentyczność. Finalnie obraz po siedemdziesięciu dwóch latach wrócił do Muzeum Narodowego w Warszawie, które po II wojnie światowej było prawnym spadkobiercą zbiorów po Towarzystwie Zachęty ${ }^{5}$. Przypadek ten jest przykładem na prawidłowe podejście i szybką reakcję w związku z uzyskaną informacją oraz umiejętne wykorzystanie źródła informacji, jakim jest zawartość Internetu.

${ }^{3} \mathrm{http} / /$ www.artinfo.pl/pl/katalog-aukcji/aukcja/6eaa9b40/kobieta-w-pawich-piorach [dostęp 15.02.2017]; http://ryneksztuki.eu/index.php?option=com_content\&task=view\&id=59\&Itemid=2 [dostęp 15.02.2017]; http://www.artinfo.pl/pl/katalog-aukcji/szukaj/?page=11\&prange=20\&sparam $\mathrm{s}=$ author_id:10667\&sort=2\&direction=2 [dostęp 15.02.2017].

${ }^{4}$ http://www.nimoz.pl [dostęp 15.02.2017]; http://dzielautracone.gov.pl [dostęp 15.02.2017].

${ }^{5}$ Sprawa 2Ds. 2455/11 prowadzona przez Prokuraturę Rejonową w Łodzi. 
Kolejnym i bardziej złożonym przykładem jest sprawa dotycząca głównie ograbiania grobów i miejsc spoczynku poległych żołnierzy z okresu I i II wojny światowej, znieważenia szczątków ludzkich oraz innych wątków ${ }^{6}$. Dochodzenie wszczęto w związku z zawiadomieniem o czynie z art. $262 \S 2 \mathrm{k} . \mathrm{k}$. w sprawie ograbiania zwłok, grobów i innych miejsc spoczynku zmarłych pochowanych w miejscowości Gadka Stara, woj. łódzkie na terenie cmentarza wojennego z okresu I i II wojny światowej przez firmę ekshumacyjną. W trakcie prowadzonych czynności dokonano przeszukania pomieszczeń należących do jej właściciela oraz pracowników na terenie woj. łódzkiego oraz w woj. opolskim. W toku tych czynności ujawniono w bardzo dużej liczbie przedmioty z okresu I i II wojny światowej wykopane podczas zakończonych nawet kilka lat wcześniej ekshumacji, łącznie ponad tysiąc przedmiotów, a także szczątki ludzkie. Oprócz przedmiotów osobistych poległych żołnierzy i zabytkowych elementów wyposażenia, które mogą być przedmiotem zainteresowania kolekcjonerów, zabezpieczono broń palną, amunicję i materiały niebezpieczne pochodzenia wojennego (Grajewski 2016a, 87-102). W związku z prowadzoną sprawą analizowano wszystkie napływające dane. Brano również pod uwagę informacje pojawiające się na internetowych forach dyskusyjnych, a także wiadomości z mediów. Dzięki tym informacjom udało się ustalić osoby posiadające wiedzę na temat nieprawidłowości podczas prowadzonych prac ekshumacyjnych?

W związku z czynnościami prowadzonymi przez funkcjonariuszy Wydziału Kryminalnego KWP w Łodzi związanymi z informacją w sprawie osób dokonujących nielegalnych poszukiwań zabytków, dokonano przejrzenia filmów zamieszczonych na internetowym portalu youtube.com. Zamieszone tam filmy i komentarze dotyczyły grupy około dziesięciu osób dokonujących nielegalnych poszukiwań8. W trakcie czynności ustalono, że jeden z filmów, na którym utrwalona jest interwencja policji, podjęta podczas poszukiwania zabytków, został nakręcony na polu w powiecie brzezińskim. Dalsze czynności przy udziale specjalisty archeologii w Wojewódzkim Urzędzie Ochrony Zabytków w Łodzi pozwoliły ustalić, że na polu tym ulokowane jest stanowisko archeologiczne, którego niszczenie jest przestępstwem. Ponadto ustalenia potwierdziły liczne zabytki archeologiczne zarejestrowane na filmie, znalezione przez bohaterów filmu za pośrednictwem wykrywacza metalu. Na pozostałych filmach również widoczne są

${ }^{6}$ Sprawa Ds. 405/12 prowadzona przez Prokuraturę Rejonową w Pabianicach.

${ }^{7}$ Dyskusje na forach internetowych, np. http://odkrywca.pl/pierwszy-zolnierz-wykopany, 119286.html [dostęp 15.02.2017]; informacje z mediów na temat nieprawidłowości podczas ekshumacji, np. http://wisla.naszemiasto.pl/archiwum/ekshumacji-zolnierzy-niemieckich-dokonanowbrew-wszelkim,1450136,art,t,id,tm.html [dostęp 15.02.2017].

${ }^{8} \mathrm{https}: / / w w w . y o u t u b e . c o m / w a t c h ? \mathrm{v}=\mathrm{HW} 5 \mathrm{tWw} 0 \mathrm{GjWM}$ [dostęp 1.03.2016]; https://www.youtube.com/watch? $\mathrm{v}=\mathrm{dgB} 9 \mathrm{w} 59 \mathrm{c} 2 \mathrm{Lw}$ [dostęp 1.03.2016]; https:/www.youtube.com/watch? $\mathrm{v}=\mathrm{Xmy}-$ -3oEJR4w [dostęp 1.03.2016]; https://www.youtube.com/watch? $v=r 3 R X e z R e J U k$ [dostęp 1.03.2016].

${ }^{9}$ Sprawa PR 1Ds.68.2016 prowadzona przez Prokuraturę Rejonową w Brzezinach. 
osoby, które z wykrywaczami metalu poszukują zabytków. Wykopują one zabytki archeologiczne, a także materiały niebezpieczne w postaci pocisku artyleryjskiego oraz amunicji karabinowej i pistoletowej. Dodatkowo, podczas analizy treści zmieszczonych w Internecie ustalono, że to jedna osoba umieściła na portalu internetowym youtube.com kilka filmów, na których wspólnie z innymi dokonuje przestępczego procederu nielegalnego poszukiwania zabytków i wykopywania amunicji. Po dokonaniu analizy materiału filmowego oraz materiałów zamieszczonych na innych dostępnych portalach internetowych w postaci zdjęć i filmów umieszczanych przez te osoby podjęto próbę identyfikacji tych osób. Na podstawie zgromadzonego materiału prokuratura wydała postanowienia o przeszukaniu pomieszczeń mieszkalnych i zatrzymaniu jedenastu osób biorących udział w tym procederze. W trakcie czynności zatrzymano dużą ilość zabytków, militariów, a także amunicję. Wśród odzyskanych zabytków znajdował się fragment cennego skarbu z epoki brązu, w skład którego wchodziło 25 siekierek i 2 bransolety. Była to pozostała część skarbu przekazanego wcześniej Mazowieckiemu Wojewódzkiemu Konserwatorowi Zabytków w liczbie 24 siekierek i 3 bransolet z epoki brązu, który mając wiedzę, że pochodzi z przypadkowego odkrycia w trakcie ,poszukiwania robaków na ryby” wystąpił do Ministra Kultury z wnioskiem o nagrodę dla znalazcy. W związku z nowymi ujawnionymi okolicznościami najprawdopodobniej nagroda zostanie cofnięta, a zatrzymany odpowie również za wprowadzenie w błąd w celu osiągnięcia korzyści w postaci nagrody od Ministra Kultury. Znaleziony skarb w takiej liczbie siekierek jest unikatowy. Z uwagi na olbrzymie znaczenie naukowe i wartości historyczne niewątpliwie stanowi dobro o szczególnym znaczeniu dla kultury.

Przypadków, w których olbrzymią rolę odegrała informatyka śledcza, jest dużo więcej, a jej katalog zastosowania nie zamyka się na omówionym powyżej wycinku przestępstw przeciwko zabytkom. W 2007 r. w strukturach Wydziału Kryminalnego KWP w Łodzi powołano Zespół zajmujący się tą problematyką. Od czasu jego powstania do dnia dzisiejszego w województwie łódzkim w związku z przestępstwami przeciwko dziedzictwu narodowemu zatrzymano około pięćdziesiąt siedem osób, w tym czterdzieści pięć dokonujących zniszczenia i przywłaszczenia zabytków archeologicznych podczas nielegalnych poszukiwań ${ }^{10}$. Nadmienić należy, że oprócz odzyskanych zabytków zatrzymano kilkanaście sztuk broni palnej, dużą ilość amunicji różnego kalibru oraz materiały wybuchowe, głównie pochodzenia wojennego. Odzyskano szereg utraconych zabytków figurujących w internetowych bazach danych Narodowego Instytutu Muzealnictwa i Ochrony Zbiorów w postaci m.in. zabytków sakralnych, malarstwa, starodruków. Odzyskano obraz figurujący w katalogu strat wojennych Ministerstwa Kultury i Dziedzictwa Narodowego. Ponadto praca łódzkich funkcjonariuszy przyczyniła się do odzyskania bardzo dużej liczby niezinwentaryzowanych

${ }^{10}$ Opracowanie własne. Informacje zebrane przez autora (stan na 15.02.2017). 
zabytków pochodzących z kradzieży dokonywanych na stanowiskach archeologicznych, polach bitewnych i towarzyszących im mogiłach (Grajewski 2016b, 65-85). Prawie 90 procent informacji na temat osób mających związek z tym procederem pochodziło z Internetu. Po kilku latach działalności Zespołu zaobserwowano radykalne ograniczenie na terenie województwa łódzkiego wolnego handlu internetowego zabytkami pochodzącymi z nielegalnych wykopalisk i podniesienie powszechnej świadomości na temat problemu, jakim jest zagrożenie dla stanowisk i zabytków archeologicznych przez nielegalne poszukiwania skarbów. $\mathrm{W}$ walce $\mathrm{z}$ tym przestępstwem istotne jest również przygotowanie merytoryczne oraz zaangażowanie funkcjonariuszy zajmujących się tym zagadnieniem $\mathrm{w}$ jednostkach policji. Duże znacznie ma też współpraca z osobami wywodzącymi się m.in. z kolekcjonerów lub pasjonatów, którzy profesjonalnie obracają zabytkami i dziełami sztuki w domach aukcyjnych. W większości osoby te ze względu na wykształcenie są w stanie przeprowadzić właściwą analizę ich pochodzenia. To także od nich w dużej mierze zależy, aby rynek nielegalnie obracający dobrami kultury lub falsyfikatami stał się niszowy. Niepokojący obecnie jest wzrost liczby kolekcjonerów zainteresowanych poszukiwaniami militariów. Zjawisko to stanowi poważne zagrożenie dla materialnych pozostałości historii okresu I i II wojny światowej, które coraz częściej jest dostrzegane przez służby konserwatorskie (Ogrodzki 2010, 9-11). Można wysnuć wniosek, że pomimo iż przez Internet przechodzi najwięcej kontrowersyjnych zabytków, to nadal niedostatecznie pracuje się nad tym, aby wyeliminować ten proceder. Podniesienie znaczenia roli informatyki śledczej w monitorowaniu tego zagadnienia i rozwijającego się rynku zabytków niewątpliwie poprawi stan ich ochrony prawnej, niwelując zagrożenia, jakie obecnie czyhają na zabytki i dzieła sztuki.

\section{BIBLIOGRAFIA}

Bernatek-Zaguła, Izabela. 2012. „Prawna ochrona dóbr kultury - problemy terminologiczne”. Przeglad Prawa Konstytucyjnego 4: 135-149.

Gadecki, Bartłomiej. 2014. Ustawa o ochronie zabytków i opiece nad zabytkami. Art. 108-112. Przepisy karne. Komentarz. 16, 41. Warszawa: C.H. Beck.

Gadecki, Bartłomiej. 2015. „Karnoprawna ochrona zabytków architektury”. W Wandalizm wobec dziedzictwa naturalnego i kulturowego. Red. Wiesław Pływaczewski, Szymon Buczyński. 56-57. Olsztyn: Uniwersytet Warmińsko-Mazurski.

Grajewski, Adam. 2016a. „Problematyka prawno-kryminalistyczna okradania oraz nielegalnych ekshumacji grobów wojennych”. W Przestępczość przeciwko dziedzictwu kulturowemu. Diagnoza, zapobieganie, zwalczanie. Red. Maciej Trzciński, Olgierd Jakubowski. 87-102. Wroclaw: Uniwersytet Wrocławski.

Grajewski, Adam. 2016b. „Przykłady spraw realizowanych przez Zespół do Zwalczania Przestępczości Przeciwko Dziedzictwu Narodowemu WK KWP w Łodzi”. W Stużby w ochronie dziedzictwa Europy Wschodniej. Materiaty pokonferencyjne, Pęzino 14-15 VI 2016. Red. Marek Łuczak. 65-85. Szczecin. 
Gruza, Ewa, Mieczysław Goc, Jacek Moszczyński. 2011. Kryminalistyka - czyli rzecz o metodach śledczych. 571-572. Warszawa: Wydawnictwa Akademickie i Profesjonalne.

Grzegorczyk, Tomasz, Janusz Tylman. 2005. Polskie postępowanie karne. 417-419. Warszawa: LexisNexis.

Grześkowiak, Alicja, Krzysztof Wiak (red.). 2014. Kodeks karny. Komentarz. 974-975. Warszawa: C.H. Beck.

Mądrzejowski, Wiesław. 2012. „Biały wywiad w Policji”. W Biały wywiad. Otwarte źródła informacji - wokót teorii i praktyki. Red. Wojciech Filipkowski, Wiesław Mądrzejowski. 117-128. Warszawa: C.H. Beck.

Michalak, Anna, Artur Ginter. 2016. Ustawa o ochronie zabytków i opiece nad zabytkami. Komentarz. 144-156. Warszawa.

Ogrodzki, Piotr. 2010. Przestępczość przeciwko zabytkom, krótka charakterystyka problemu. Stan na rok 2010. Katalog utraconych dzieł sztuki Cenne, bezcenne/utracone. Wydanie specjalne. 9-10. Warszawa: Nimoz.

Rudnicki, Grzegorz, Jolanta Rudnicka, Stanisław Rudnicki. 2016. Kodeks cywilny. Komentarz. Tom II. Własność i inne prawa rzeczowe. 508-536. Warszawa: Wolters Kluwer.

Saramak, Bartosz. 2015. Wykorzystanie otwartych źródet informacji w działalności wywiadowczej: historia, praktyka, perspektywy. 108-110. Warszawa: Uniwersytet Warszawski.

Stefański, Ryszard Andrzej. 2004. „Przestępstwo znieważenia zwłok, prochów ludzkich lub grobu (art. 262 k.k.)". Prokuratura i Prawo 10: 19-28.

Stromczyński, Błażej, Paweł Waszkiewicz. 2014. „Biały wywiad w praktyce pracy organów ścigania na przykładzie wykorzystania serwisów społecznościowych”. Prokuratura i Prawo 5: 158-163.

Trzciński, Maciej. 2010. Przestępczość przeciwko zabytkom archeologicznym problematyka prawno-kryminalistyczna. 49-60, 187-200. Warszawa: Wolters Kluwer.

Ziółkowski, Wojciech. 2006. „Przestępczość w Internecie przeciwko zabytkom archeologicznym”. Cenne, bezcenne/utracone 2 (47): 13-15.

\section{Akty prawne}

Rozporządzenie Ministra Kultury i Dziedzictwa Narodowego z dnia 27 lipca 2011 r. w sprawie prowadzenia prac konserwatorskich, prac restauratorskich, robót budowlanych, badań konserwatorskich, badań architektonicznych i innych działań przy zabytku wpisanym do rejestru zabytków oraz badań archeologicznych (Dz. U. 2011, Nr 165, poz. 987).

Umowa między Rządem Rzeczypospolitej Polskiej a Rządem Federacji Rosyjskiej o grobach i miejscach pamięci ofiar wojen i represji, sporządzona w Krakowie dnia 22 lutego 1994 r. (Dz. U. z dnia 21 października 1994 r.).

Umowa między Rządem Rzeczypospolitej Polskiej a Rządem Republiki Federalnej Niemiec o grobach ofiar wojen i przemocy totalitarnej, podpisana w Warszawie dnia 8 grudnia $2003 \mathrm{r}$. (M.P. z dnia 23 września 2005 r.).

Ustawa z dnia 23 kwietnia 1964 r. Kodeks cywilny (Dz. U. 1964, Nr 16, poz. 93).

Ustawa z dnia 21 listopada 1996 r. o muzeach (Dz. U. 2012, poz. 987).

Ustawa z dnia 6 czerwca 1997 r. Kodeks karny (Dz. U. 1997, Nr 88, poz. 553).

Ustawa z dnia 21 maja 1999 r. o broni i amunicji (Dz. U. 1999, Nr 53, poz. 549).

Ustawa z dnia 23 lipca 2003 r. o ochronie zabytków i opiece nad zabytkami (Dz. U. 2003, Nr 162, poz. 1568).

Ustawa z dnia 20 lutego 2015 r. o rzeczach znalezionych (Dz. U. 2015, poz. 397). 


\title{
Strony internetowe
}

http://dzielautracone.gov.pl [dostęp 15.02.2017].

http://odkrywca.pl/pierwszy-zolnierz-wykopany,119286.html [dostęp 15.02.2017].

http://ryneksztuki.eu/index.php?option=com_content\&task=view\&id=59\&Itemid=2 [dostęp 15.02.2017].

http://wisla.naszemiasto.pl/archiwum/ekshumacji-zolnierzy-niemieckich-dokonano-wbrew-wszelkim,1450136,art,t,id,tm.html [dostęp 15.02.2017].

http://www.artinfo.pl/pl/katalog-aukcji/aukcja/6eaa9b40/kobieta-w-pawich-piorach [dostęp 15.02.2017]. http://www.artinfo.pl/pl/katalog-aukcji/szukaj/?page=11\&prange=20\&sparams=author id:10667\&sort=2\&direction=2 [dostęp 15.02.2017].

http://www.nimoz.pl [dostęp 15.02.2017].

https://www.youtube.com/watch?v=dgB9w59c2Lw [dostęp 1.03.2016].

https://www.youtube.com/watch?v=HW5tWw0GjWM [dostęp 1.03.2016].

https://www.youtube.com/watch? $\mathrm{v}=\mathrm{r} 3 \mathrm{RXezReJUk}$ [dostęp 1.03.2016].

https://www.youtube.com/watch?v=Xmy-3oEJR4w [dostęp 1.03.2016].

\section{Adam Grajewski}

\section{PRACTICE OF USING THE INTERNET IN FIGHTING CRIME AGAINST MONUMENTS}

\begin{abstract}
We are seeing a change in the development of science, which draws forensics knowledge and use of the achievements, adapting them to fight crime. Modern forensics does not stop at the same adaptation of the achievements of other sciences, but also independently develops its own methods and means of fighting crime, which is associated with ongoing technological progress and the growing needs of law enforcement and forensics. Collected during the activity traces of forensic science today, we can identify using modern technologies. It is now possible, thanks also obtained new sources of personal and work hard analytical, investigative and operational. As practice shows the basis for the initiation of proceedings may also be electronic evidence, which can be found by analyzing the content of the Internet.
\end{abstract}

Keywords: weapon, law, archeology, monument, criminalistics, computer forensics. 